\title{
Forum
}

\section{Wissenschaft des Judentums as a Paradigm for New Muslim Approaches to Islam}

\author{
by \\ Khaleel Mohammed
}

Although Wissenschaft des Judentums was the brainchild of German Jews, it reflected the aims of European Jews in general. As noted by the late Professor Amos Funkenstein, "even if we grant that the majority of traditional Jews in France, Austria, and Germany were not aware of the full scope of the achievements of the Wissenschaft, its results nevertheless faithfully reflected the desires and self-image of nineteenth-century Jews craving for emancipation, the mood of the "perplexed of the times." the Enlightenment did little to change the lot of the Jew: he was still seen by many as a Christ-killer, his identity linked to a particular nation-and he could, therefore, never be fully accepted as part of any other national entity. Although some Jews may have become totally assimilated and even converted to Christianity, the general perception was that the Jews wanted to be conditional citizens: while adopting the culture of the environment, they wanted to preserve their special nature as a subculture. ${ }^{2}$ 
Today, in the aftermath of the Holocaust, the establishment of a Jewish state, and the willingness of superpowers to pledge their unwavering support of the modern state of Israel, institutional Judeophobia has largely disappeared. Sophisticated and critical approaches to the study of Judaism have relegated some of the works of early Wissenschaft to being dusty, unread tomes on library shelves. In North American universities, mention of names like Leopold Zunz, Heinrich Graetz, Abraham Geiger, and Simon Dubnow often draws looks of bewilderment on the faces of many university students who consider themselves familiar with Jewish history. But for any Muslim historiographer or social scientist, these names and their contributions to Wissenschaft des Judentums should be a paradigm for designing a response to the crisis of contemporary Islam and Muslims. This paper examines some early aspects of Wissenschaft, considering the perspectives of Abraham Geiger (1810-1874) and Simon Dubnow (1860-1941) as guides for reformist Muslim scholars in the Western world. Abraham Geiger and Simon Dubnow were among the most outstanding Wissenschaft scholars of their time; they came from different backgrounds, and as will be shown later, their differences of perspective in a common enterprise mirror similar diversity among today's scholarly Muslims in their relation to Islam. ${ }^{3}$

I need to point out here that the German discipline of Islamwissenschaft and its Anglophone equivalent of Islamic studies cannot be deemed as a parallel to Wissenschaft des Judentums because, as I noted earlier, Wissenschaft des Judentums was designed by Jews in response to a particular set of circumstances. Islamwissenchaft and Islamic studies were not initiated by Muslim scholars, but rather by outsiders with a polemic purpose that still persists, albeit with reduced potency. ${ }^{4}$ The task at hand for Western-based Muslim scholars is to either redefine those disciplines, as did the Jewish scholars who extended the dimension of Wissenschaft, or to pioneer a totally new approach. The former choice seems much more simple and functional. The cultural particularization implicit in the focus on Western Muslims does not deny that there is benefit for Muslim reformists in general; it is just that the discussion of the different circumstances and approaches of a global consideration would be extremely lengthy and beyond the scope of this article. The choice of the time of this period is because the circumstances for Jews in nineteenth and early twentieth century Europe are similar to that of Muslims in the Western world today. Any historians, reflecting on the institutional demonization of the pre-Yom Ha'atzmaut (Independence Day) European Jewish Diaspora, must experi- 
ence a sense of déjà-vu as they reflect on the words of Professor Iftikhar Malik:

After the Second World War, the Jews in Europe and North America may have obtained more breathing space and political influence but the predicament of their other counterparts still remains unsolved. Within Europe and North America, their fellow monotheists-suffering from institutional racism and even outright discrimination - are the Muslim Diasporas, who have never had smooth sailing and 9/11 has definitely turned them into the 'new Jews' of the West. ${ }^{5}$

Indeed, the similarities of circumstances between today's Muslims in the Western world and the pre-Yom Ha'atzmaut Jewish Diaspora are overwhelming. Like nineteenth-century European Jews, many Muslims want to adopt the culture of the Western lands in which they live, but they also desire to maintain their religious ideas in a way that often serves to identify them as an identifiable subculture. ${ }^{6}$ In a predominantly Christian West, Muslims, by dint of their not accepting Jesus as divine, are often deemedlike Jews - to be spiritually incomplete. Yet, for the most part, institutional Judeophobia is something of a bygone era; for Muslims, the continuing demonization is so pernicious and pervasive that, as Edward Said puts it:

Malicious generalizations about Islam have become the last acceptable form of denigration of foreign culture in the West; what is said about Muslim mind, or character, or religion, or culture as a whole cannot be said in mainstream discussion about Africans, Jews, other Orientals, or Asians. $^{7}$

That Muslims should learn from Jewish mazkirim (chroniclers) is not something new. In the Qur'an, Muhammad is directed: "If you are in doubt concerning that which We have revealed unto you, then ask those who read the scripture before you" (Qur'an 10:94). The Qur' an further instructs Muhammad's contemporaneous Arabs that they should ask the Jewish chroniclers for information about the earlier prophets that are mentioned in the Qur'an (Qur'an 16:43, 21:7). ${ }^{8}$ If later Muslim exegetes reinterpreted the meaning of the terms used to refer to Jewish historians, evidence can be found in a hadith, ${ }^{9}$ Islam's oral tradition, which has Muhammad saying to his followers, "Relate from the Children of Israel, and there is no objection in that." ${ }^{10}$ Ibn Khaldun, the medieval polymath, notes in his Muqaddimah that, before the rise of Islam, whenever the Muslims wanted to know about events of the past, they consulted the Jewish scholars. ${ }^{11}$ 
Based on their view of the Qur'anic imperative, the hadith instruction, and the normal practice of the Arabs, medieval Muslims sought such copious recourse in Jewish traditions that a specific name was coined for this genre of literature: the Isra'iliyaat. ${ }^{12}$ The considerable evidence of such material in the formation of early Islamic writings, led Nabia Abbot to conclude that the Islamic traditions came to resemble the Mishnah ${ }^{13}$ more than any other sacred literature of the People of the Book. ${ }^{14}$ Quite early, however, under the rubric of Isra'iliyaat, several aspects of folklore that clashed with the message of the Qur'an were imported into Muslim tradition. Isra'iliyaat evolved to indicate material that came from any nonMuslim source, and then to refer to anything that was considered seditious to Islamic belief. Eventually, this source of information that had previously been seen as scripturally mandated was largely shunned.

Arab-Israeli tensions have exacerbated the situation, resulting in a collision between many Jewish and Muslim scholars. Each group vies to create a more damaging counterhistory of the other, "simmering in a mutually destructive cauldron of hatred and denigration." 15 Many modern Jewish scholars are Zionist, and their writings and ideologies may be perceived by Muslim as alien to Islamic interests. For the purposes of this paper, this is one of the factors that motivated my selection of the perspectives of Geiger and Dubnow as more paradigmatic than later scholars.

Early Wissenschaft as a model for Muslim scholarship is not only because of the similar circumstances that necessitate the need for a new approach. It is because that even though some early scholars-among them Simon Dubnow - rejected a belief in God, Wissenschaft des Judentums "for most of its history was to varying degrees and in very different ways predominantly a religious enterprise." ${ }^{16}$ Nearly all of its leading scholars in Germany were rabbis and considered their task an intrinsically religious one. Its luminaries were on the faculties of seminaries, and their students were mainly Jews. ${ }^{17}$ In like manner, instead of being completely neutral academic researchers, the majority of Muslims who try to find new approaches to Islam are either scholars of religion or those who identify themselves as observant Muslims. Among them are Seyyed Hossein Nasr, Fazlur Rahman, Ismail Raji al-Faruqi, Taha Jabir Al-Alwani, Rachid Gannouchi, Farid Esack, Abdul-Karim Soroush, Riffat Hassan, Mahmoud Ayoub, and Mohammad al-Ashmawy.

Those who were involved in the studies of Semitics at universities did not consider themselves to be involved in the same enterprise as the Wissenschaft des Judentums practitioners. ${ }^{18}$ In like manner, the scholars of Is- 
lamwissenschaft cannot be considered as addressing Islam from within. The most prominent names associated with early Islamwissenschaft are non-Muslim-among them, Georg Freytag, Antoine Isaac Silvestre de Sacy, Abraham Geiger, Gustav Weil, Theodor Nöldeke, Aloys Sprenger, and Ignaz Goldziher - all of whom were non-Muslims and all of whom, it might be argued, sought in varying degrees from an Orientalist perspective to critique Islam. Islamic Studies of today have grown out of Near Eastern or Oriental Studies, conducted from the perspective of overly gross generalizations and simplifications. ${ }^{19}$ Muslim World, one of the most influential journals in the field, came out of the Hartford Seminary, and was initially aimed at debunking Islam in order to aid the spread of Christianity. There is no record of any Muslim scholar being associated with the initial formation of these Western approaches to the study of Islam. Fazlur Rahman, in the latter part of the twentieth century, was the first outstanding Muslim personality to recognizably and winningly challenge some of the prevailing opinions.

Therefore, Wissenschaft des Judentums cannot be paralleled to Islamwissenschaft or Islamic studies. Even today, Jewish studies and Islamic studies cannot be seen as the same sides of the same coin: professors of Jewish studies (at least in North America) are almost overwhelmingly Jewish, whereas in Islamic studies, despite the presence of a number of Muslim faculty members, the discipline is still largely controlled by non-Muslims. ${ }^{20}$ The books used in Islamic studies are still largely of non-Muslim authorship, and the most famous scholars in the field are non-Muslims.

For all the perceived religiosity of Wissenschaft des Judentums, it ought to be noted that many of the scholars associated with the movement sought to distinguish between their scientific approach and theology. The reason was rather simple, and aptly put by the historian Isaac Marcus Jost, who noted that religious belief "cast the historian in chains from which one must break free if one is to be true to the critical method." ${ }^{21}$ It is this same tension that today plays itself out among Muslim scholars. While many of the Muslim scholars cited earlier do identify themselves as observant of the distinction between an approach and theology, most of them do not function within seminarian institutions but rather within secular universities. Taha al-Alwani is the only person among those mentioned earlier that works under the auspices of the International Institute for Islamic Thought (IIIT), an organization that some may identify, rightly or wrongly, as a seminary. However, even within the group of those who identify themselves as working outside of theology, the same tensions that were experienced by the 
Jewish scholars exist. For example, I as a Muslim, while seeking to adhere to both faith and academic integrity, clash with some of my coreligionists on many creedal issues. It seems clear then that there is a close similarity of outlook between the contemporary Muslims and their counterparts, the earlier Jewish paradigm shapers.

Even though Geiger and Dubnow were pre-Yom Ha'atzmaut, unless one is able to plausibly advance an argument in their defense, some of their views on Islam may alienate Muslim thinkers. Islamwissenschaft pioneers largely credited Abraham Geiger for his work on Islam, and many considered it the most seminal work on the issue of foreign influences..$^{22}$ Geiger's thesis Was Hat Mohammad aus dem Judenthume aufgenommen was developed from a paper presented in a competition sponsored by one of the most noted Islamophobes of the time, Professor Georg Wilhelm Freytag, himself the protégé of the French Arabist, Antoine Isaac Silvestre de Sacy. Later research was to find several problems in Geiger's formulations. ${ }^{23}$ He had operated largely on the idea of Islam's wholesale borrowing from Judaism, not entertaining the idea of common origins and ancient bonds between Hebrews and Arabs - a theory that was advanced by a contemporary, Heinrich Ewald. Geiger, for example, frequently posited Qur'anic borrowings from the Pirke De-Rabbi Eliezer, ${ }^{24}$ not realizing that the latter document was composed after the advent of Islam. ${ }^{25}$ Geiger's views of Islam are indeed problematic when one reflects on some of them - such as for example, "There is hardly a word for 'holy' in the Arabic Language" 26 In assessing Muhammad, he seems to have not fully availed himself of original sources, preferring rather to rely on Sprenger as "a thorough and competent investigator," and therefore describing Muhammad as having a "devotion with treachery." 27

Geiger, a rabbi and historian, obviously was writing primarily as a Jew to bring about reform and to counteract the prevalent anti-Jewish feelings. He was also convinced of Jewish superiority over all other religions of antiquity, and of its noble culture and positive influence on all humanity. ${ }^{28}$ In a Christocentric Europe that was completely dismissive of Islam, when objective scholarship was something not yet known with regards to the perceived "Other," one could expect little else of Geiger. He was embarking on a rather ambitious project: destroying the then counterhistory of Judaism. Geiger intended to use Wissenschaft as the new German-Jewish historiography to argue that it was not Greece, Rome, or Aryan culture, or the Christian testament, which were responsible for the advanced Western culture - but that it was Judaism..$^{29}$ In her masterful study of Geiger, 
Susannah Heschel has pointed out that during the Middle Ages, it was a common anti-Semitic practice to blame Judaism for the rise of Islam. Geiger's approach was to not deny any of this, but to skillfully show that in its dependence on Jewish tradition, Islam was totally a human concoction and absolutely unoriginal. ${ }^{30}$ - that is, whatever good that was in Islam was from Judaism, and the bad was because of the innate backwardness of Muhammad and his Arabs. ${ }^{31}$ It was on the basis of Geiger's writings that, until the ideas of Christian provenance were propounded by Torrey and Bell, German scholars christened Islam as schmarotzergewächs-a parasitic growth out of Judaism. ${ }^{32}$

Simon Dubnow had a similar agenda to Geiger's. Dubnow did not know Arabic and was unable, therefore, to research material on Islam from primary sources. As Oscar Handlin points out in the introduction to Dubnow's History of the Jews, his weaknesses as a historian were the due to the parochial limitations of his culture. ${ }^{33}$ His reports about Muhammad and the condition of Jews in Arabia are unreferenced, unquestioningly accepted from whatever source he obtained them. Dubnow had given up believing in God, and may have stridently opposed certain aspects of Jewish religious ritual and law, but his divorcement from the Jewish community was more imagined than real. ${ }^{34}$ In studying history to argue against the traditional Jewish leadership and belief, he came to understand the role that religion was a dynamic ideal that had ensured the survival of the Jews in the past. ${ }^{35}$ (As his grandson has noted, he did attend the synagogue on the High Holidays. ${ }^{36}$ )

There can be no doubt then about his deep consciousness and emotional attachment to his Jewishness, and his resulting tendentiousness in certain areas. He found it difficult to ascribe any responsibility to the Jews for their woes. They always were, in his view, the innocent victims of persecutions - even when, as Michael Meyer points out, that in the Chmielnicki massacres of 1648, some Jews served the interests of the Polish nobility and played a role in oppressing Ukrainian peasants. ${ }^{37}$ When Jewish settlers were beginning their struggle to establish a foothold in Palestine, writing like Geiger, Dubnow would certainly have identified with the struggles of his people-and that meant using the material of the day: the Orientalist approach that provided the license to present the stereotype of the uncivilized Arab, and to create a counterhistory of Muslims and their prophet.

Even though academics now see the two men as reflecting the limitations of their times and learning, and writing with a particular agendum in mind, some of the problematic formulations of Geiger and Dubnow are 
still accepted as "truths" on Islam. The fact is that in the study of history, extrapolations are often difficult to prove or disprove and all that remains for Muslims to do is offer a reliable rebuttal where necessary. Both scholars, for example, wrote of Muhammad turning toward Jerusalem in prayer to appease the Jews in the hope that they would convert to Islam, ${ }^{38}$ and they maintained that when the mass conversions did not occur, Muhammad supposedly changed the direction toward Mecca. Fazlur Rahman has convincingly rebutted this allegation, pointing out that it comes out of an exaggeration of the role of Medinese Jewry on the development of Islam. The argument, as propounded, would have made more sense if Muhammad had appointed Jerusalem as the qiblah on his arrival in Medina to woo the Jews. But the change seems to have occurred in Mecca (where no Jewish presence is noted), and most likely at the time when the Ka'bah was filled with idols and closed to Muslims. It was, therefore, in Mecca that the original change was made, and it was done in order to emphasize the difference between Muslims and pagans. The Muslims, too, could have kept Jerusalem as the qibla while dissociating it from Judaism - as the Qur'an had done with Abraham, declaring him to be neither a Jew nor a Christian. ${ }^{39}$

If Muslims can understand the perspectives of Geiger and Dubnow in context-indeed, the reason why early Wissenschaft scholars, and even current Jewish Israel-centric writers who express a negative view of Islam-then perhaps it would be easier for them to approach Wissenschaft des Judentums in a more accepting manner. The main aim, after all, is not to the study of Wissenschaft to learn about Jewish views on Muhammad and Islam, but to understand and utilize the discipline's methodology. However, despite this obvious logic, the fact is that for most Muslims, the respect for Muhammad is so great that it is not easy for them to seek information from any source that disparages him. It is for this reason that I have dealt with matter in such detail. Muslim obsession with the person of Muhammad strangely serves as one of the most potent rebuttals to Geiger's summation of Islam's prophet: that " $[\mathrm{H}] \mathrm{e}$ was not a great man, had not the moral superiority, that silent grandeur to chain minds to him. . .."40

For Geiger, Wissenschaft provided the basis for study of what in the Jewish tradition was elemental and, therefore, to be preserved, and what was peripheral and could be discarded. It provided the recipe for reform, unshackling Judaism from the rigid and often inaccurate traditional ideas and strengthening the religion. As Geiger noted, revelation and tradition are important, but tradition is that which changes to ensure transformation according to the changing wants and necessities of life. ${ }^{41}$ This position was 
opposed to the orthodox stance, which saw all tradition as being linked to Sinai and, therefore, not subject to change. In an essay that he wrote in 1835 , Geiger lambasted the orthodox rabbis for their opposition to every innovation designed for the purpose of making the sermons understandable to the congregation, whereas the prayers would be rendered in German instead of Hebrew that few German Jews understood..$^{42} \mathrm{He}$ went as far as writing:

The Talmudical writings contain legends of many kinds. They are the products of the people's poetic imagination, folklore, brought about by a people when on the child's plane, bearing its mark. One hardly knows whether they are a merry play of poetic fancy or arise with a claim of full belief: such twilight of opinion corresponds to the child's plane of culture. ${ }^{43}$

This view of Geiger, along with his reform initiative, is an interesting lesson for Muslims. For centuries, they have viewed the Qur'an as an immutable document, and the Hadith, the Muslim oral traditions, as being a manifesto for all time. The ideas of veiling, the segregation of sexes, of a woman getting half the amount of her male counterpart in most cases of inheritance, and the antiquated ideas of interest and usury in financial transactions continue to present hurdles to assimilation and a harmonious interaction with non-Muslims. Fazlur Rahman's view that the Qur'an is inimitable rather than immutable was not received well among his coreligionists, and although he became an icon among Western students of Islam, he was effectively ostracized by the faith-based ulama. ${ }^{44}$ Any approach outside of the classical formations is still liable to be met with disapproval by the traditional scholars of Islam. Nasr Abu Zayd's view that the Qur'an is "a text like any other text," related to culture and context, caused him to be excommunicated from Islam according to an edict from the scholars at AlAzhar University. ${ }^{45}$ Muhammad al-Ghazali's idea of treating the Qur'an as a whole, rather than taking verses in isolation, while a great step forward, still harbors a hermeneutic that relies upon the Hadith literature - and, thus, severely comprises the idea of the Qur'an qua independent document. ${ }^{46}$

Concomitant with Geiger's views of the oral tradition were his ideas about the need for a new approach to Judaism. The Berlin Reform Association (Reformgemeinde) sought the abolition of praying with covered heads and blowing the shofar on the New Year. Rather than maintaining the antiquated, outer forms of Jewish tradition, the Berlin Association proclaimed: 
we want to understand the sacred Scriptures according to the Divine Spirit, not according to the letter. ... We can no longer recognize a code as an unchangeable law-book which maintains with unbending insistence that Judaism's task is expressed by forms which originated in a time which is forever past and which will never return. ... Thus placed between the graves of our fathers and the cradles of our children, we are stirred by the trumpet sound of our time. It calls us to be the last of a great inheritance in its old form, and at the same time, the first who, with unswerving courage and bound together as brothers in word and deed, shall lay the cornerstone of a new edifice for us and for the generations to come. ${ }^{47}$

Abraham Geiger, for all his sometimes radical views, was determined to maintain some sort of unity, avoiding schisms and bringing about change through persuasion rather than by secession, by evolution not by revolution. ${ }^{48}$ He later chose to accept some of the very practices he had opposedan example being circumcision, which he felt was not part of pristine Judaism; yet he was opposed to its abrogation. ${ }^{49}$ For him, a critical study of Judaism would show that its spirit lay in ethical monotheism - and that this was adaptable to place and time by creating new tradition..$^{50}$

It might be argued that reformist ideation in the nineteenth century was not unknown in Islam - and that the work of Geiger's contemporaries, among them Sayyid Muhammad Ahmad in India and Jamal al-Din al-Afghani in the Arab world, are examples of this this movement. But apart from the difference in methodologies, there is also the issue of locus: Wissenschaft occurred in Europe where the Jews were a threatened minority; however, the attempts at Islamic reform by contrast occurred in either Muslim lands or where the Muslims were the de jure rulers. The aim of Geiger's reform, too, was to allow for some sort of conditional assimilation; by contrast, the Muslim attempts were to establish independent continuity and to resist or minimize foreign colonialist influences on Islam. The attempts to involve secular sciences in Muslim reform were not welcomed and most of those movements, for all their claimed success, were eventually unsuccessful. Al-Azhar University, which was one of the earlier targets of Al-Afghani's work, is still a bastion of conservatism, and the Aligarh University that Sayyid Muhammad Ahmad founded seems to be returning to a more conservative outlook. ${ }^{51}$

In today's West, Muslim scholars are as divided as Geiger and his Jewish contemporaries on the issues of what is integral to faith. For all their differences, however, most are coming to grips with the need for reevaluation of Islamic legal thought. The initial work of Fazlur Rahman at Chi- 
cago University has been followed today by the writings of scholars like Taha al-Alwani, Khalid Abou el-Fadl, Rifat Hassan, Azizah al-Hibri, and Abdullahi al-Na'im. Each one of them is known as a critic of the traditional approaches and interpretations of Islamic law.

Taha al-Alwani has coined the term fiqh al-aqalliyaat ( $f i q h$ for minorities), in contradistinction to the idea of classical Islamic law, which had been formulated under Muslim rule and where Muslims were the majority. Like classical Halakha, many interpretations of Islamic law are antiquated and often present severe obstacles for Muslims to function as productive citizens in Western culture. An example is the gender segregation that some Muslims see as being divinely ordained for all time. Almost like Geiger in relation to tradition, al-Alwani writes:

"Fiqh for minorities" is a specific term which takes into account the relationship between the religious ruling and the conditions of the community and the location where it exists. It is a figh that applies to a specific group of people living under particular circumstances with special needs that may not be appropriate for other communities. Besides religious knowledge, practitioners of this figh will need a wider acquaintance with several social sciences disciplines, especially sociology, economics, political science and international relations. ${ }^{52}$

Rather strangely, al-Alwani does not refer to the modern study of religion in Western universities and the hermeneutical theories that can be imported from that discipline. Despite his critique of taqlid (the traditional adherence to established legal understanding), and calling for a new ijtihad (juristic methodology), al-Alwani does not wish to upset the classical view of the Qur' an as "immutable and incontrovertible." ${ }^{33}$ In this way, he differs from both Geiger and Fazlur Rahman. The title of one of al-Alwani's coauthored texts The Qur'an and the Sunnah: The Time-Space Factor might imply that he is referring to the temporality of Qur'anic legislation. ${ }^{54}$ But, while he does point out that the Qur'anic revelations were connected with specific situations and events, he deadens the impact of this admission by saying that "People would then be able to understand it and fix its words, meanings, guidelines and directives permanently in their consciousness. ${ }^{55}$ He further states:

The Qur'an contains basic conceptions and general rules, guidance and advice valid for all human beings in every place and time and every realm of life. If it had dealt with minor details and issues relevant to the period of Revelation, it would not have acquired this unique quality of 
time-space universality. . . . The specific issues that are dealt with in fine details are essentially the same objectives and rules applicable in every time-space situation and relate to 'ibada (worship), inheritance, and histories of early peoples and nations. ${ }^{56}$

The statements are ambiguous at best, for they do not address with clarity the concept of ratio legis - and as addressed by Fazlur Rahman, the temporality of the actual legislation:

[W]hereas the spirit of the Qur'anic legislation exhibits an obvious direction towards the progressive embodiment of the fundamental human values of freedom and responsibility in fresh legislation, nevertheless the actual legislation of the Qur'an had partly to accept the then existing society as a term of reference. This clearly means that the actual legislation of the Qur'an cannot have been meant to be literally eternal by the Qur'an itself. ${ }^{57}$

Al-Alwani's formulation, while it sounds similar to that of Geiger and Rahman, differs in terms of the source text's permanency of legislation. It also exhibits a factor that is still missing from contemporary Islam: Geiger combined a strong secular and seminarian education; his contributions fell in both spheres. Rahman was deemed an academic and, as earlier noted, largely ostracized by the faith community, and his writings, while famous among specialists in Islam in Western universities, are almost unknown among the traditional ulama and imams. Al-Alwani, a graduate of Azhar, although a reformist at heart, seems bound by the very tradition he wishes to reform. With the possible exceptions of a few - such as Mahmoud Ayoub, Abdul Aziz Sachedina, Seyyed Hossein Nasr, and Ismail al-Faruqithere are not many names among Muslim scholars that claim to be a Muslim counterpart of Geiger: secular in education, and functional within the religious institution. Even in the case of these scholars, unlike al-Alwani, their participation is limited as they are not imams or leaders in the sense of having effective participation among the Muslim leaders. Since the other contemporary Islamic scholars mentioned earlier are all academics, their views are not relevant here as they operate within a secular domain.

The lack of wishing to put the Qur'an into context for its content and temporality is a serious problem for Muslim scholars. Especially since $9 / 11$, there has been an increasing amount of popular literature that denigrates the scripture of Islam, deeming it as a text of violence. ${ }^{58}$ Often referring to verses taken out of context, or without the requisite knowledge to put texts into context, or failing to understand the role of commentaries, 
non-Muslims maintain this attack. The attack is not only in the popular arena: when Professor Carl Ernst recommended the use of Michael Sell's translation of the Qur'an for a summer reading program at the University of North Carolina in Chapel Hill, North Carolina, a Virginia-based Christian group sued the university, arguing that the university was trying to convert students to Islam. ${ }^{59}$ In April 2002, the Los Angeles School District banned the use of Yusuf Ali's translation because its footnotes were considered anti-Jewish. ${ }^{60}$ Muslim responses have been largely unnoticed-partly because of the media stereotypes of Muslims and partly because there is no studied, agree-upon approach to the issue by the Muslim scholars, an approach that is jointly accepted by those in the faith-based and secular milieus. Adding to the problem of the attacks from the outside, there is also the issue of converts to Islam writing and spreading the most pernicious and misleading information about Islam.

Muslim scholars might learn from Simon Dubnow's analysis of attacks on Jewish tradition and scripture from both within and without. In 1239, a French Jew who had converted to being a Dominican, and wanted to prove the sincerity of his conversion, complained to Pope Gregory IX that the Talmud contains insulting material against Jesus and Christians. ${ }^{61}$ A commission was drawn up to investigate the charges, all based on citations from the Talmud. Dubnow notes:

A rationalist from the school of Maimonides could easily have repudiated all those charges, through the assertion that the Jewish faith is not responsible for that entire literature ... just as Christianity is not responsible for all the writings of the Church Fathers and of the authors of the biographies of the saints which contain aspersions and religious intolerance no less than the Talmud. ${ }^{62}$

Of more importance, however, is that Dubnow was perceptive enough to identify the problem of the Jewish defense; he points out that Rabbi Yechiel of Paris and his consultants regarded the Aggadah ${ }^{63}$ as holy and, therefore, found themselves in a dilemma-circumventing the issues of the more offending citations, and seeking to temper them by showing others that exhorted acts of charity and care to all, regardless of faith.

Dubnow could, like Geiger, afford this harsh criticism toward the Talmud. For many Muslim imams, the Hadith is perceived in much the same way as Rabbi Yechiel and his Tosefta ${ }^{64}$ companions viewed the Talmud (though strict comparison between the Hadith and the Talmud may be an exaggeration). Even when Muslims identify that the Hadith is not on the 
same level as the Qur' an, they nonetheless use it as a valuable tool in interpretation, with some even seeing it as a source of divinely revealed knowledge ${ }^{65}$ This puts Muslims in an untenable position when asked to explain some of the more terrible aspects of Hadith, such as those that speak of the terrible battles at the end of time between Muslims and Jews. ${ }^{66}$

In order to question its traditions, or considering radical re-approaches to its main scripture, institutional Islam seems averse to employing the latest theories advanced in Western studies of religion. Without the acknowledgement of intertextuality, brought on perhaps by the stigma attached to Isra'iliyaat discussed earlier, Muslims are often limited in their interpretive approaches to certain Qur'anic verses - one of the most notable examples being the references to Jewish mazkirim in the Qur'an (16:43, 21:7) ${ }^{67}$ By contrast, Dubnow, having stepped out of the limits of religious faith, could objectively assess the religion, and Geiger, while questioning tradition, did not see it affecting his faith. There are Muslims like myself who question many parts of the tradition, but such a discourse cannot be objectively conducted within a mosque. In this particular case, Geiger and Dubnow (as indeed, all early Reform Jewish scholars) ought to be studied for new approaches to examining cherished traditions.

In the second decade of the twenty-first century, Muslims in Europe and North America continue to encounter harsh discrimination. At least thirteen states have had hearings against the implementation of Shar'iah law, even though there is no movement by any registered national Muslim group to implement such. As if the discrimination against person and religion is not enough, Pastor Terry Jones in Florida even held a trial against the Qur'an. ${ }^{68}$ Dina Temple-Raston, America's National Public Radio's FBI correspondent notes, "There is an expression in the black community that in white America everyone who is black is born suspect. Today, post 9/11, that has come to also define the condition of Muslims here." ${ }^{69}$ Her book on the trial of the first group of those accused of home-grown terrorism in the United States provided an interesting statistic:

Between September 2001 and September 2006 . . . the government indicted 417 people after terror investigations. ... Of course, "supporting terrorism" had come to have a rather broad definition and didn't require any intent to commit a criminal act in the United States at all. ... Four people among these suspects were actually convicted of terrorism charges. ${ }^{70}$ 
A Canadian resident of Syrian origin, Maher Arar, was arrested on a trip to the United States, and with no firm evidence or due legal process, he was spirited away to Syria. There, he was tortured; he was released only after tremendous effort by his family members with the backing of several associations. The Canadian government ended up apologizing to him for its conduct and had to pay ten million dollars to him in damages. ${ }^{71}$ Based on trumped-up charges, Murat Kurnaz, a German resident of Turkish origin, spent five years in Guantanamo. He has documented in excruciating detail the cruelty and miscarriages of justice meted out to him by the American government, along with the complicity of some Pakistani and German officials - even though his innocence was obvious quite early in his detention. $^{72}$

The situation of the Muslims is not unlike an earlier incident that is referred to as the Dreyfus Affair that occurred in 1894. Accused of espionage simply because of his Jewishness, this French officer was convicted, largely by pressure from anti-Semites, and sent to the penal colony on Devil's Island. ${ }^{73}$ The conviction of Dreyfus led to a terrible situation for French Jews: they were subjected to slander and condemnation, and investigations into prosecutorial misconduct of the case were thwarted several times. The matter has long been a defining example of the maltreatment of Jews in France, and Jewish historians have chronicled the matter in detail.

In like manner, several books are now emerging on the detention of Muslims in the United States on trumped-up charges. The difference is that, in many cases, the authors of such books are not themselves Muslim, but are simply incensed at the rise of bigotry and bias. Muslim scholars still have to learn from the Wissenschaft des Judentum pioneers about the need to present their history without apologetic and religious rhetoric and in a manner that is readable and presentable to the average non-Muslim.

In the preceding portions of this article, I have only dwelt on a paltry number of issues. There are certainly factors that dictate a mutatis mutandis adoption of the Wissenschaft des Judentums paradigm. The Jews that contributed to Wissenschaft des Judentums were part and parcel of their environment, and scholars who could in many cases be important in both the secular and seminarian worlds. They spoke the language of their environment with native fluency. In many cases, the Muslims are still identifiable immigrants - different in color, culture, and accented language. Until either time or education removes these descriptions, their efforts will only have marginal success. They will also have to learn that certain ideas will have to be avoided. Any concept that seemingly resembles Dubnow's 
Diaspora nationalism must be steadfastly eschewed for two main reasons: (1) Islam is a religion comprised of adherents from myriad cultures; and (2) since there is a war on terror, such ideation will only foment Othering and alienation. ${ }^{74}$

Popular books, television shows, and a war against terrorism in which the Muslim is the perceived enemy have created a situation that is still being played out in the post-9/11 rise of zealous nationalism. Muslim self-examination and what is deemed as sympathetic scholarship from non-Muslims have been met with concerted opposition. Professor Laurie Brand, chairperson of the Middle East Studies Association's Committee on Academic Freedom notes:

In the United States, there is no question that members of the Middle East studies community have been disproportionately targeted . . . have been victims of ugly smear campaigns regarding their scholarship; several tenure cases have triggered vicious, high profile "extramural" attacks against junior faculty, and in a handful of cases, our colleagues have been barred from giving talks or participating in educational events, owing to their political positions on Middle East-related issues. ${ }^{75}$

This means that Muslims have to not only be resolute in their attempt to change the way Islam and Muslims are studied, but they have to carefully construct their efforts, looking outward as well as inward. Anything perceived as pure Muslim apologetic, or Muslims writing only for Muslims, will be problematic. Certainly, as in every religion, the rift between Western-trained Muslim academics and the institutional imams will continue. In some cases, there have been attempts to bridge the divide between faith and academe. The International Institute for Islamic Thought (IIIT), a think tank founded in Herndon, Virginia in 1981, and composed of scholars and religious leaders, has all the objectives that indicate its desire to pioneer a modern Islamic version of Wissenschaft. It is financially self-sufficient, and supports universities in Malaysia and Pakistan. It publishes books from both a confessional and academic perspective, and oversees several academic journals. IIIT offers in Herndon, Virginia regular summer courses, scholarships, and internships to Muslims and non-Muslims. Its leadership and intellectual core is, however, still largely comprised of an immigrant population, and its most outstanding scholars are overwhelmingly Arabtherefore, their interpretations of Islam is substantially different from that of their Western coreligionist colleagues. This foundation continues to try to cooperate with scholars working within secular universities, and will 
no doubt experience the difference of perspectives that characterized early Wissenschaft-reflected, for example, in the case of Geiger operating within the rabbinate and university, and Dubnow working outside of the sphere of religion. In America, many Muslim scholars within the university environment have published material focused on new approaches to and interpretations of Islam. If a synergistic relationship can be reached between them and the IIIT, then they will most certainly repeat for Islam what Geiger and his colleagues did for Judaism:

Wissenschaft des Judentums . . gave a new elite the right to interpret texts, sometimes radically, on the basis of external historical knowledge. Had it been wholly secular in its orientation, it could have been more easily dismissed by champions of the traditional interpretations. ${ }^{76}$

Despite Geiger's desire that his movement not break the overall Jewish unity, Judaism evolved to accept denominational designations. This, however, did not threaten the religion and culture as a whole, but rather amazingly ensured an evolving, dynamic form of Judaism. This is one of the most vital-and difficult lessons-for Islam. Many Muslims still work within the fetters of a tradition that calls for a unified interpretation of Islam. This has for centuries proven untenable, and even from the earliest days of formative Islam, scholars recognized different schools of creed and of law. Different movements within Judaism - such as Orthodox, Conservative, Reform, and Reconstructionist-all have their de facto counterparts within Islam. However, presently among most Muslims, there is no institutional recognition of these differences. An Islamic tradition observes that there would come a time when Muslims would follow the Jews and Christians and fragment into sects, destroying the unity of Islam. ${ }^{77}$ Paradoxically, it would seem that if present-day Muslims want to save Islam, they will have to embrace a Wissenschaft des Judentums paradigm along with its attendant denominationalization; this is not a matter of choice-but, to use an Islamic fiqh term: darüra (a necessity). 


\section{Endnotes}

1. Amos Funkenstein, Perceptions of Jewish History (Berkeley, CA: University of California Press, 1993), 19.

2. Ibid., 20.

3. At this juncture, I must point out that all of the material in my educational institution of the writings of the Wissenschaft scholars is not in the original German. Since, however, such translations have been accepted by my peers and specialists in the field without any known charges of mistranslations, I have spared myself the arduous task of locating the original publications.

4. However, some may argue that, in view of the avalanche of vitriolic antiMuslim polemic, Islamophobia is at its worst level.

5. Iftikhar Malik, Crescent Between Cross and Star: Muslims in the West after 9/11 (Karachi, Pakistan: Oxford University Press, 2006), 288. The term new Jews to describe the Muslims was first used by the Syrian Journalist Rana Kabbani in an article she wrote for the Guardian newspaper in 1992; cited in Iftikhar Malik, Crescent Between Cross and Star, 326.

6. Taha Jabir al-Alwani, Towards a Fiqh for Minorities: Some Basic Reflections, trans. Ashur A. Shames Hernandon, VA and Surrey, UK: 2003), xv.

7. Edward Said, Covering Islam: How the Media and the Experts Determine How We See the Rest of the World (New York: Vintage Books, 1997), xi-xii.

8. Khaleel Mohammed, “The Identity of the Qur'an's Ahl al-Dhikr," in Coming to Terms with the Qur'an, ed. Khaleel Mohammed and Andrew Rippin (Haledon, NJ: Islamic Publications International, 2008), 33-45.

9. There are certain differences between the hadith (report) and sunna (practice), but these are of a specialist demarcation. Throughout this paper, I use hadith to refer to both terms.

10. Narrated in such compilations as Sahih al-Bukhari, Sahih Muslim, Sunan alTirmidhi, Sunan Ibn Majah, and Musnad Ahmad. As entered in Al-Mu'jam al-Mufahras li Alfaz al-Hadith al-Nabawi (A Concordance and Index of the Prophetic Traditions), 8 vols. (Leiden, The Netherlands, Brill, 1936), vol. 1, 434. For a particularly good analysis of this tradition, see M. J. Kister, Haddithu an Bani Isra'il wa la Haraj (Relate from the Children of Israel Without Restriction)," Israel Oriental Studies 11 (1972): 215-39.

11. Ibn Khaldun, The Muqaddimah: An Introduction to History, trans. Franz Rosenthal, 3 vols. (New York: Pantheon Books, 1958), vol. 2, 445. See also Akram Diya al-'Umari, Madinan Society at the Time of the Prophet (Herndon, VA: International Institute of Islamic Thought, 1991), 44.

12. See Muhammad al-Dhahabi, "Isra'ilitic Narratives in Exegesis and Tradition," (paper presented at the Fourth Conference of the Academy of Islamic Research, Cairo, 1970), 586. See also Khaleel Mohammed, “The 
Jewish and Christian Influences on the Eschatological Imagery of Sahih Muslim" (M.A. thesis, Concordia University, Montreal, 1997), 4.

13. Mishnah: the earliest compilation of the Jewish oral law (s.v. mishnah in Oxford Dictionary of World Religions, ed. John Bowker. (Oxford and New York: Oxford University Press. 1997), 645.

14. Nabia Abbot, Studies in Arabic Literary Papyri, 3 vols. (Chicago, University of Chicago Press, 1957-1972), vol. 2, 8.

15. Malik, Crescent Between Cross and Star, 288.

16. Michael A. Meyer, "Two Persistent Tensions within Wissenschaft Des Judentums," in Modern Judaism 24, vol. 2 (2004), 105.

17. Ibid.

18. Ibid.

19. Mohamed Arkoun, "Islamic Studies," in The Oxford Encyclopedia of the Modern Islamic World, ed. John Esposito, 4 vols. (New York Oxford University Press, 1995), vol. 2, 332-40.

20. Michael Meyer observes that in Germany, scholars of contemporary Jewish studies are predominantly non-Jewish. See Meyers, "Two Persistent Tensions within Wissenschaft Des Judentums," 114.

21. As cited in Michael A. Meyer "Two Persistent Tensions within Wissenschaft Des Judentums," 106.

22. See Susannah Heschel, Abraham Geiger and the Jewish Jesus (Chicago: University of Chicago Press, 1998), 59.

23. See Norman Stillman, "The Story of Cain and Abel in the Qur'an and the Muslim Commentators: Some Observations," Journal of Semitic Studies 19 (1974): 231-39.

24. Pirke De Rabbi Eliezer: an eighth-century homiletic work. (s.v. Pirke in Oxford Dictionary of World Religions, 754).

25. Norman Stillman, "The Story of Cain and Abel in the Qur' an and the Muslim Commentators: Some Observations."

26. Abraham Geiger, Judaism and Its History (Lantham, MD: University Press of America, 1985), 250. His summation is rather surprising, and one is left to question the depth of his Arabic training. The Hebrew qoddesh is a cognate of the Arabic quddus.

27. Ibid., 254.

28. Ibid., 26.

29. Susannah Heschel, "Revolt of the Colonized: Abraham Geiger's Wissenschaft des Judentums as a Challenge to Christian Hegemony in the Academy," New German Critique 77 (1999): 61-85.

30. Susannah Heschel, Abraham Geiger and the Jewish Jesus, 59.

31. Geiger, Judaism and Its History, 253-55.

32. Heschel, Abraham Geiger and the Jewish Jesus, 59. 
33. Oscar Handlin "Introduction," in Simon Dubnow, History of the Jews, tr. Moshe Spiegel, 5 vols. (South Brunswick, N.J and London: T. Yoseloff, 1967), vol. 1, 5.

34. David Weinberg, Between Tradition and Modernity, (New York and London: Holmes and Meier, Inc., 1996), 156.

35. Ibid, 157.

36. Victor Erlich, "Life with Grandfather," in Sophie Dubnov-Erlich, The Life and Work of S. M. Dubnov (Bloomington, IN: Indiana University Press, 1991), 251.

37. Michael Meyer, Ideas of Jewish History (Detroit, MI: Wayne State University), 34-35.

38. Geiger, Judaism and Its History, 258; Simon Dubnow, History of the Jews, vol. 2, 314.

39. Fazlur Rahman, Islam (Chicago: University of Chicago Press, 1979), 20.

40. Geiger, Judaism and Its History, 252-55.

41. Ibid., 86 .

42. Alexander Altman, Essays in Jewish Intellectual History, (Hanover, NH: University Press of New England, 1981), 222.

43. Abraham Geiger, Judaism and Its History, 319.

44. Rahman, Islam, 39

45. Nasr Hamid Abu Zayd, Mafhum al-Nass: Dirasa fi 'ulum al-Qur'an [The Understanding of the Text: a Study in the Sciences of the Qur'an] (Beirut, Lebanon: Al markaz al thaqafi al arabi, 1998), 10, 19.

46. Muhammad al-Ghazali, A Thematic Commentary on the Qur'an, tr. Ashur Shamis, (Herndon, VA and Surrey, UK: International Institute of Islamic Thought, 2000.

47. Michael A. Meyer, and Wolf Gunther Plaut, ed. The Rise of Reform Judaism: A Sourcebook of Its European Origins, (New York: World Union for Progressive Judaism, 1963), 57.

48. Khaleel Mohammed, "Abraham Geiger and Heinrich Graetz: A Comparison of their Different Perspectives on Jewish Historiography," in Journal of Religion and Culture, 11 (Spring 1997): 144.

49. Bernard Martin, A History of Judaism, 2 vols. (New York: Basic Books, 1974), vol. 2, 239.

50. Ibid.

51. As noted in Akbar Ahmed, Journey into Islam: the Crisis of Globalism (Washington, DC: Brookings Institute Press, 2007), 74-82.

52. Taha Jabir al-Alwani, Towards a Fiqh for Minorities, 3.

53. Ibid. ,9.

54. Taha Jabir al-Alwani et al., The Qur'an and the Sunnah: The Time-Space Factor (Herndon, VA and Surrey, UK: International Institute of Islamic Thought, 1991).

55. Ibid., 12 (italics mine). 
56. Ibid.

57. Rahman, Islam, 39. By understanding ratio legis, the reasoning behind a particular law, contemporary Muslim jurists can apply the general moralsocial objectives for modern rulings, rather than seek to adhere to antiquated laws. See Fazlur Rahman, Islam and Modernity: Transformation of an Intellectual Tradition (Chicago: University of Chicago Press, 1982), 5-7.

58. Good coverage of this is provided in Iftikhar Malik, Crescent; Akbar Ahmed, Islam Under Siege (Cambridge, UK, 2003); Robert Jewett and John Shelton Lawrence, Captain America and the Crusade Against Evil: The Dilemma of Zealous Nationalism (Grand Rapids: MI: W. B. Eerdmans, 2003.

59. See CarlErnst, Following Muhammad:Rethinking Islam in the Contemporary World (Chapel Hill, NC: University of North Carolina Press, 2003), xiv.

60. "L.A. Schools Review Donated Korans, Citing Derogatory Commentary," Magazine of the American Library Association, February 11, 2002.

61. Dubnow, History of the Jews, vol. 3, 44-45.

62. Ibid.

63. Aggadah (also Haggadah): rabbinic homiletic and nonlegal narratives. (s.v. aggadah in Oxford Dictionary of World Religions, 29).

64. Tosefta: a suplementary work to the Mishnah. (s.v. Tosefta in Oxford Dictionary of Worpld Religions, 986).

65. Taha Jabir al-Alwani, Issues in Contemporary Islamic Thought (London and Washington: International Institute of Islamic Thought, 2005), 5.

66. For a good discussion on this hadith, see Khaleel Mohammed, "Produce your Proof: Muslim Exegesis, the Hadith and the Jews," Judaism 209 and Judaism 210, no. 1-2 (2004): 3-11.

67. Khaleel Mohammed, "The Identity of the Qur'an's Ahl al-Dhikr."

68. Cf.www.usatoday.com/news/religion/2011-03-21-quran-burning-florida_N. htm, accessed April 22, 2011.

69. Dina Temple-Raston, The Jihad Next Door: The Lackawanna Six and Rough Justice in an Age of Terror (New York: PublicAffairs, 2007), xiv.

70. Ibid, 243.

71. Robert Palliter and William Weaver, Presidential Secrecy and the Law (Baltimore, MD: John Hopkins University Press, 2007), 109, www.cbc.ca/ news/yourview/2007/01/ottawa_reaches_10m_settlement.html.

72. Murat Kurnaz with Helmut Kuhn, Five Years of My Life: An Innocent Man in Guantanamo, trans. Jefferson Chase (New York: Palgrave Macmillan, 2008).

73. Dubnow, History of the Jews, vol. 5, 605-606.

74. "The consciousness of the nationality itself is the main criterion of its existence," in Simon Dubnow, Nationalism and History, ed. Koppel S. Pinson (Philadelphia, PA: Jewish Publication Society of America, 1958), 98. 
75. Laurie Brand, "Academic Freedom: Responsibilities in the Current Environment," International Journal of Middle East Studies, 40, no. 2 (May 2008): 188.

76. Michael Meyer, "Two Persistent Tensions within Wissenschaft Des Judentums," 108.

77. Muhammad Ibn Isa al-Tirmidhi, Jami al-Tirmidhi [The Compendium of al-Tirmidhi] (Riyadh, Saudi Arabia: Bayt al Afkaar al Duwaliya, n.d.), 428, entry 2640. 